Research Article

\title{
Public Sector Advisory Services for Rice Productivity: A Case Study of Farmers' Awareness in Tehsil Shakargarh of Pakistan
}

\author{
Muhammad Yaseen $^{1 *}$, Muhammad Sallam Shahzad ${ }^{2}$, Farhat Ullah Khan ${ }^{2}$, Muhammad Luqman ${ }^{1}$ Usman \\ Saleem $^{3}$ and Shoaib Nasir ${ }^{4}$
}

${ }^{1}$ Department of Agricultural Extension, College of Agriculture, University of Sargodha, Sargodha, Pakistan; ${ }^{2}$ Department of Agricultural Sciences, Allama Iqbal Open University, Islamabad, Pakistan; ${ }^{3}$ Department of Plant Breeding and Genetics, College of Agriculture, University of Sargodha, Sargodha, Pakistan; ${ }^{4}$ Department of Agribusiness and Applied Economics, MNS-University of Agriculture, Multan, Pakistan.

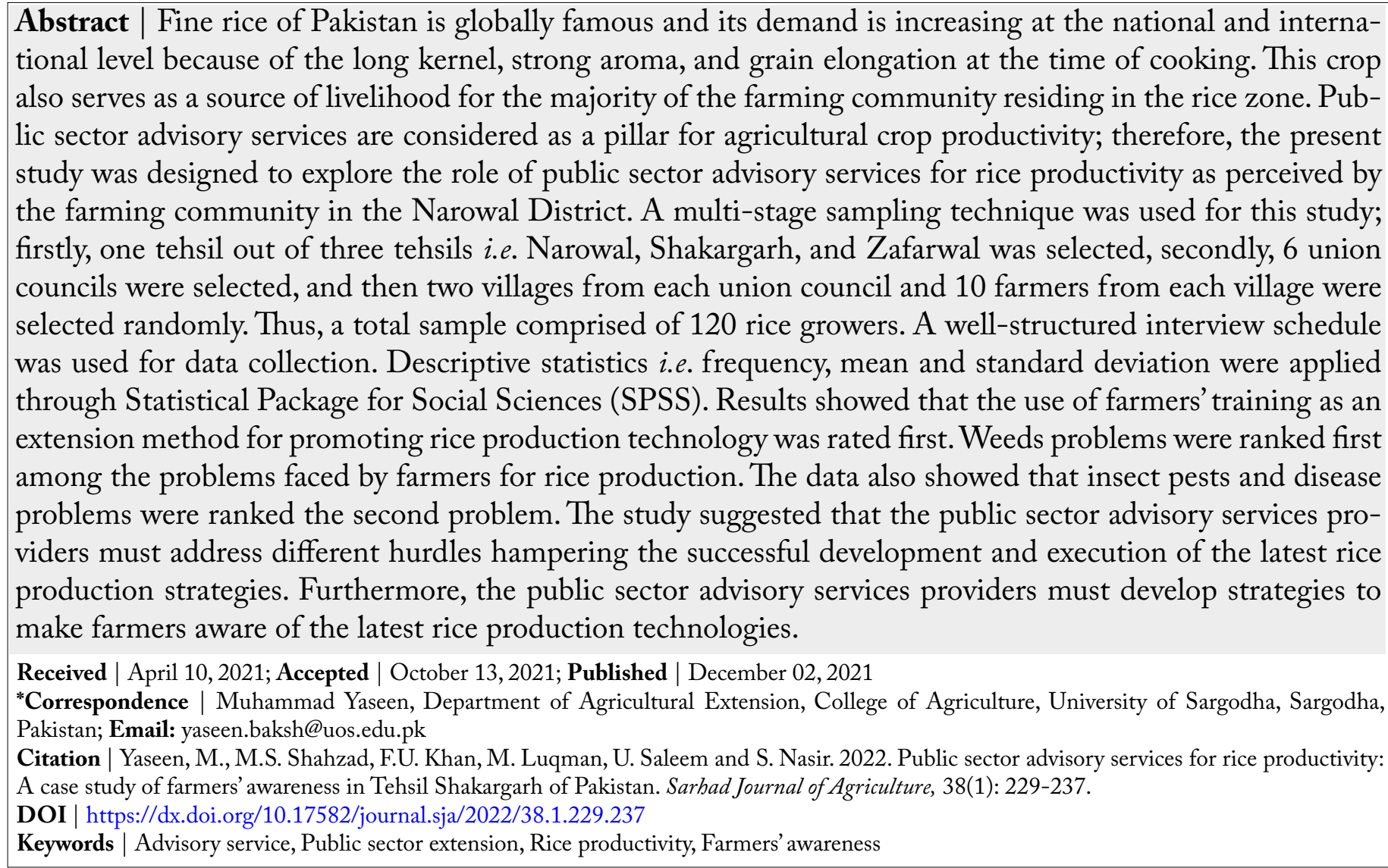

\section{Introduction}

I $\mathrm{n}$ Pakistan, rice (Oryza sativa L.) is the second most important crop as a staple food after wheat and also the most important product for export after cotton. Its share in agriculture is nearly $3 \%$, however, its share in the GDP has been recorded as $0.6 \%$. It was cultivated on an area of 2810 thousand hectares with a production of 7202 thousand tonnes in 2018-19, significant decrease has been observed in rice cultivation area and production as compared to the previous year. This declining trend was due to decreased cultivation 
area, dry weather, and water shortage (GoP, 2019). Regardless of various problems in rice cultivation, $\mathrm{Pa}-$ kistani basmati rice gained increasing demand at the national and international market because of its quality characteristics like long kernel, strong aroma, and a most importantly high degree of grain elongation at the time of cooking (Shahzadi et al., 2018). Rice crop plays a great part in the reclamation of saline soils providing the opportunity for agriculture productivity, where no other crops could grow (Zelensky, 1999). Generally, it is perceived that un-accessibility and non-availability of technical and latest knowledge regarding different farm activities were the most important factors responsible for lower production of rice (Muhammad and Garforth, 2007). Rice crop was observed sensitive to climate change; therefore, climate change adaptation strategies for crop productivity should be streamlined in various cropping zones (Ednhofer et al., 2014; Siddiqui et al., 2012).

Extension and advisory services in agriculture are indispensable and it offers more than just expert assistance in the improvement of production and processing; it also enables a flow of information and transfer of knowledge and scientific findings. Extension services are performed to regulate and establish farmers' organizations; functioning according to goals, and ways to execute outreach activities by the extension field staff (Tborn, 2011). The major function of agriculture extension is to educate farmers and enable them to solve agricultural problems. Finding the best suitable solutions for the problems and the practical performance of these solutions is the functional objective of agriculture extension (Rivera and Qamar, 2003). Agricultural extension and advisory services are very important in the development of rural knowledge and innovative systems and influence rural household decisions, especially in the developing countries which are generally more in need of such guidance services (Alex and Zijp, 2002). Public sector extension services are important actors to stimulate the development of agricultural production. Therefore, agricultural extension services must be designed to improve farming skills among farmers and sensitize them to acquire new knowledge and technologies to improve farm productivity (Qamar, 2005).

Increased investment in extension and crop productivity requires a certain radical change in the existing behavior patterns of the farmers (Saeed, 2011; Sikkema, 2017) and the working strategies of extension personnel. Recommended practices and production technology for crop productivity are not adopted by farmers (Mwangi and Kariuki, 2015; Aslam, 2016) due to diversified problems faced by rice growers like; inadequate education, lack of technical knowledge, poor quality \& scarcity of water (Rehman et al., 2015; Ashfaq et al., 2003; Ahmad and Yohannes, 2010), improper soil fertility, lack of capital, irrigation water, credit facility, unavailability of latest $\&$ suitable varieties and lack of access to latest farm practices causes low productivity (Ahmad, 2011; Hussain, 2010; Aydin et al., 2010; Sheikh, 2010). Similarly, lack of insurance mechanism and inadequate marketing system are causes of decline in rice production (Rao, 2011; Khan, 2010; Bashir et al., 2010). Extension field staff should assess various needs of farmers to improve rice productivity, the major emerging needs of rice growers are training for rice production, disease $\&$ pest management, and fertilizer \& pesticides application (Babu et al., 2011).

Considering the above scenario the present study was conducted to explore the role of the public sector extension and advisory services for rice productivity among the farming community particularly in District Narowal. Indeed a lot of research has been accomplished in the context of rice production though, researchers paid very little attention to examine awareness among the farming community regarding public sector extension and advisory services for rice production technologies. Moreover, it is also important to assess various methodologies used by extension field staff for the promotion of rice production technologies. The research objectives of current study are to:

1. Profile various sources of information being used by the farmers for rice production

2. Assess awareness of the farmers regarding rice production technologies

3. Investigate methodologies used by EFS for promotion of rice production technologies

4. Enlist problems faced by farmers regarding rice production

\section{Materials and Methods}

Current study was conducted in District Narowal, which is one of leading rice-producing districts. District Narowal has three tehsils i.e. Narowal, Shakargarh, and Zafarwal, all rice growers of the district were considered as a population of this study. A multistage 
sampling technique was used for this study. In the $1^{\text {st }}$ stage one tehsil was selected (that was Shakargarh), in the $2^{\text {nd }}$ stage, 6 union councils (UCs) were selected out of 32 union councils of Shakargarh tehsil. In the $3^{\text {rd }}$ stage, 2 villages were selected from each UC randomly. In the $4^{\text {th }}$ and final stage, 10 farmers were selected from each village based on simple random sampling. Thus a total sample of 120 rice growers was selected for data collection. An interview schedule was prepared considering the objectives of the present study. The interview schedule was composed of various sections including; basic demographic attributes, farmers' sources of information for rice production technologies, farmers' awareness regarding rice production technologies, methodologies used by extension field staff for promotion of rice crop production technologies and farmers' problems related to rice production. Three level likert scale was used for different statements of this study and rank order was calculated on the basis of mean values. Face-to-face interviews were conducted with farmers to collect data. Farmers were approached at their homes and farms keeping in view their convenience. The collected data were statistically analyzed with the help of the Statistical Package for Social Sciences (SPSS). Descriptive statistics i.e. frequency, percentage, standard deviation, and ranking were calculated to interpret discussion.

\section{Results and Discussion}

\section{Demographic attributes}

The data shown in Figure 1 depicts that half (50\%) of the farmers were lying in the age group of 26 to 50 years. Furthermore, only $0.8 \%$ of the farmers were up to 25 years of age and nearly half $(49.2 \%)$ of the farmers were above 50 years of age. Education is an important and vital instrument for bringing about desirable change in the behavior of any individual (Khan, 2005). It is an important aspect that plays a dynamic role in developing a positive attitude among the respondents regarding innovation. Therefore, it is believed that the higher the level of education of the farmers, the better will be the output in terms of change in behavior (Rajan, 1991). The data in figure 1 indicates that half (50\%) of the farmers had completed middle level of education whereas little above one-fourth $(28 \%)$ of the farmers' group was matriculated. Only $1 \%$ of the farmers were illiterate which shows the improved educational level in rural areas of Pakistan. Some (8\%) of the farmers had a primary level of education while $13 \%$ of the farmers were above matric.
Farmers' source of income plays important role in farm management. Hence the data-inquiring sources of income of farmers are presented in Figure 1. This shows that more than half $(57 \%)$ of the farmers were relying solely on farming. Little more than one-fifth (23\%) of the farmers were having farming, as well as some type of job as a source of income, and 14\% of farmers, have farming and business as a source of income. The data also shows that some $(6 \%)$ of the farmers were doing farming as well as job and also some sort of business. The annual income of the farmers is also much important demographical factor, which depicts the financial standards of the individuals. Farmers were inquired about their annual income. The data depicting this aspect of the study is represented in Figure 1, according to which one-fifth (21\%) of the farmers had annual income above 0.2. to 0.3 million rupees whereas almost similar percentage (20\%) of the farmers were also having annual income above 0.3 to 0.4 million rupees and $21 \%$ having above 0.5 to 0.6 million rupees. Almost $9 \%$ and $8 \%$ of the farmers had an annual income of above 0.8 million rupees and 0.7 to 0.8 million rupees respectively. Only $2 \%$ of farmers have an income of 0.1 million rupees or less.

Graphical representation of the data given in Figure 1 indicates that a large percentage $(37.0 \%)$ of the farmers were cultivating rice on an area up to 5 acres whereas $35 \%$ of the farmers were cultivating rice on an area of 6 to 10 acres. Almost 13\% of the farmers were growing rice on an area between 11 to 15 acres, and $7 \%$ of the farmers were cultivating rice on an area between 16 to 20 acres while $8 \%$ of the farmers were cultivating rice on more than 20 acres of land, graphical representation of data is given in Figure 1 for further clarification. The data relating to rice yield depicts that nearly two-fifth (39\%) of the farmers were taking rice yield between 31 to 35 monds whereas a little less than one-third (33\%) of the farmers were taking rice yield between 36 to 40 monds. Some (8\%) of the farmers were also taking rice yield of above 40 monds.

\section{Sources of information}

In this section, farmers were asked about their sources of information for rice production technologies. Access to information sources is much important in the adoption process, which can lead to improvement in farmers' knowledge related to agriculture. Access to various information sources is necessary for improving rice productivity. The data depicting this aspect 


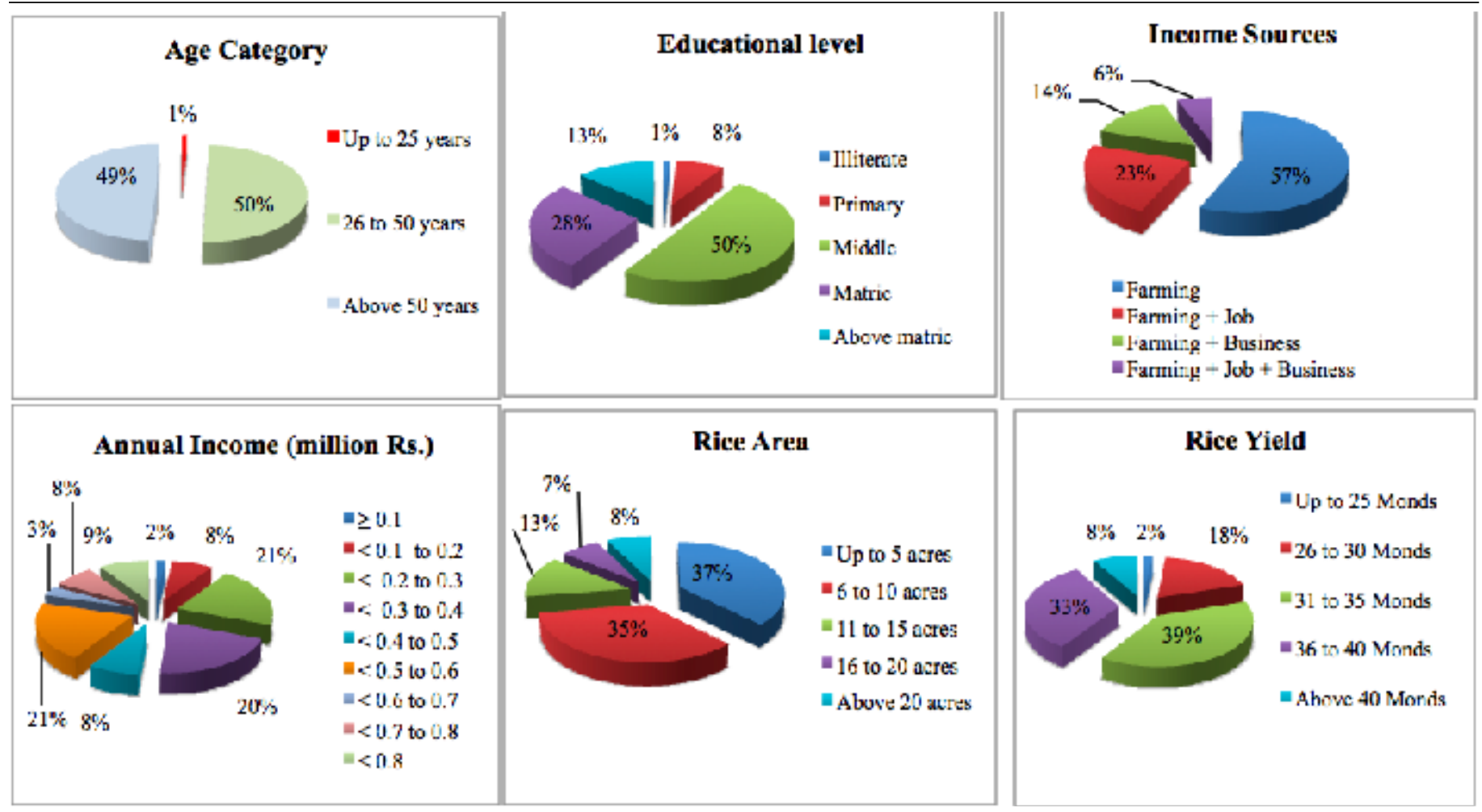

Figure 1: Respondents demographic attributes.

Table 1: Respondents' sources of information regarding rice production technologies.

\begin{tabular}{llllllll} 
Information Sources & \multicolumn{3}{l}{$\begin{array}{l}\text { Mostly } \\
\text { used }\end{array}$} & \multicolumn{3}{l}{$\begin{array}{l}\text { Sometimes } \\
\text { used }\end{array}$} & \multicolumn{2}{l}{$\begin{array}{l}\text { Rarely } \\
\text { used }\end{array}$} \\
& f & $\%$ & f & $\%$ & f & $\%$ \\
Agriculture extension de- & 71 & 59.2 & 38 & 31.7 & 11 & 9.2 \\
partment & & & & & & \\
Private companies & 28 & 23.3 & 85 & 70.8 & 7 & 5.8 \\
Pesticide dealer & 21 & 17.5 & 85 & 70.8 & 14 & 11.7 \\
Fellow farmers & 12 & 10.0 & 72 & 60.0 & 36 & 30.0 \\
Media (Electronic + Print) & 8 & 6.7 & 76 & 63.3 & 36 & 30.0 \\
Social media & 10 & 8.3 & 62 & 51.7 & 48 & 40.0 \\
TV/FM & 13 & 10.8 & 70 & 58.3 & 37 & 30.8
\end{tabular}

of the study is given in Table 1 that more than half (59.2\%) of the farmers mostly accessed the agriculture extension department for information related to rice production which shows farmers' trust in the agriculture extension department whereas $70.8 \%$ of the farmers sometimes accessed private companies for information and a similar percentage of respondents sometimes accessed pesticide dealers for information regarding rice. The table further depicts that fellow farmers were sometimes accessible by $60 \%$ of the farmers while media (electronic and print) was sometimes accessible to $63.3 \%$ of the farmers. Similarly, $51.7 \%$ and $58.3 \%$ of respondents sometimes used social media and TV/FM as information sources respectively.
Awareness regarding rice production technologies Awareness regarding rice crop production technology is much important in improving rice yield by the farming community. Farmers were asked to provide their response according to a three-level Likert scale ( $0=$ not at all aware, $1=$ slightly aware, $2=$ well aware). The results of farmers' awareness related to different practices in rice production are depicted in Table 2 which shows that more than $40.8 \%$ and $40 \%$ of the farmers were slightly aware and well aware of the wet method of nursery raising while surprisingly an overwhelming majority $(73.3 \%)$ of the farmers were not at all aware of the dry method of nursery raising \& seed rate. Except a few $15 \%$ and $11.7 \%$ were slightly aware and well aware about a dry method for nursery raising \& seed rate. Respectively huge majority (95.8\%) of the farmers were not at all aware of the Rab method of nursery raising $\&$ seed rate. More than half of (56.7\%) of respondents were not aware at all about sowing time of coarse varieties whereas $35 \%$ of the farmers were slightly aware of sowing time for fine varieties. Whereas 52.5 and $42.5 \%$ of the respondents were slightly aware and well aware about sowing time of fine varieties respectively. The data further depicts that $88.3 \%$ of the farmers were not aware at all about nursery transplantation time for coarse varieties while $45 \%$ and $38.3 \%$ of the farmers were slightly aware and well aware of nursery transplantation time for fine varieties respectively. 
Table 2: Respondents' awareness regarding rice crop production technologies.

\begin{tabular}{|c|c|c|c|c|c|c|c|}
\hline \multirow[t]{2}{*}{ Rice production technology } & & \multicolumn{2}{|c|}{ Not at all aware } & \multicolumn{2}{|c|}{ Slightly aware } & \multicolumn{2}{|c|}{ Well aware } \\
\hline & & F & $\%$ & $\mathbf{F}$ & $\%$ & $\mathbf{F}$ & $\%$ \\
\hline \multirow{3}{*}{$\begin{array}{l}\text { Nursery Raising \& Seed } \\
\text { Rate }\end{array}$} & Wet method (6-7 kg) & 23 & 19.2 & 49 & 40.8 & 48 & 40.0 \\
\hline & Dry method $(8-10 \mathrm{~kg})$ & 88 & 73.3 & 18 & 15.0 & 14 & 11.7 \\
\hline & Rab method (12-15 kg) & 115 & 95.8 & 05 & 4.20 & 0 & 0.00 \\
\hline \multirow[t]{2}{*}{ Sowing Time } & Course varieties (20 May-7 June) & 68 & 56.7 & 42 & 35.0 & 10 & 08.3 \\
\hline & Fine varieties (20 May-20 June) & 06 & 05.0 & 63 & 52.5 & 51 & 42.5 \\
\hline \multirow[t]{2}{*}{ Nursery Transplantation } & Course varieties (20 June- 7 July) & 106 & 88.3 & 09 & 07.5 & 05 & 04.2 \\
\hline & Fine varieties (20 May-20 July) & 20 & 16.7 & 54 & 45.0 & 46 & 38.3 \\
\hline \multirow{2}{*}{$\begin{array}{l}\text { Fertilizers Application (kg/ } \\
\text { acre) }\end{array}$} & Course varieties (N:P:K-69:41:32) & 102 & 85.0 & 12 & 10.0 & 06 & 05.0 \\
\hline & Fine varieties (N:P:K-57:32:25) & 11 & 9.2 & 60 & 50.0 & 49 & 40.8 \\
\hline \multirow[t]{5}{*}{ Weeds Management } & Swanky grass & 0 & 0.0 & 87 & 72.5 & 33 & 27.5 \\
\hline & Dhedan & 0 & 0.0 & 84 & 70.0 & 36 & 30.0 \\
\hline & Khabal grass & 02 & 01.7 & 81 & 67.5 & 37 & 30.8 \\
\hline & Sedge family weeds & 0 & 0.0 & 86 & 71.7 & 34 & 28.3 \\
\hline & Broad leafy weeds & 02 & 01.7 & 80 & 66.6 & 38 & 31.7 \\
\hline \multirow[t]{5}{*}{ Pest Management } & Dark headed stem borer & 12 & 10.0 & 78 & 65.0 & 30 & 25.0 \\
\hline & White stem borer & 10 & 08.3 & 73 & 60.9 & 37 & 30.8 \\
\hline & Yellow stem borer & 06 & 05.0 & 82 & 68.3 & 32 & 26.7 \\
\hline & Plant hoppers & 08 & 06.7 & 79 & 65.8 & 33 & 27.5 \\
\hline & Leaf hoppers & 12 & 10.0 & 73 & 60.8 & 35 & 29.2 \\
\hline \multirow[t]{4}{*}{ Disease Management } & Blast & 05 & 04.2 & 93 & 77.5 & 22 & 18.3 \\
\hline & Brown spot & 0 & 0.0 & 91 & 75.8 & 29 & 24.2 \\
\hline & Stem rot & 08 & 06.7 & 86 & 71.6 & 26 & 21.7 \\
\hline & Bacterial leaf blight & 05 & 04.2 & 89 & 74.1 & 26 & 21.7 \\
\hline \multirow[t]{3}{*}{ Harvesting } & Manual harvesting \& threshing & 88 & 73.3 & 14 & 11.7 & 18 & 15.0 \\
\hline & Machine harvesting \& threshing & 42 & 35.0 & 36 & 30.0 & 42 & 35.0 \\
\hline & Combine harvesting & 96 & 80.0 & 14 & 11.7 & 10 & 8.3 \\
\hline \multirow[t]{6}{*}{ Post Harvest Management } & Cutting & 22 & 18.4 & 98 & 81.6 & 0 & 0.0 \\
\hline & Hauling & 36 & 30.0 & 81 & 67.5 & 03 & 2.5 \\
\hline & Threshing & 12 & 10.0 & 104 & 86.7 & 04 & 3.3 \\
\hline & Cleaning & 23 & 19.2 & 93 & 77.5 & 04 & 3.3 \\
\hline & Field drying & 26 & 21.7 & 93 & 77.5 & 01 & 0.8 \\
\hline & Stacking/ piling & 51 & 42.5 & 67 & 55.8 & 02 & 1.7 \\
\hline
\end{tabular}

Large percentages $(85.0 \%)$ of the farmers were not aware at all about fertilizers application for coarse varieties. In addition, $50 \%$ and $40.8 \%$ of the farmers were slightly aware and well aware of fertilizer application for fine varieties. The data also depicts that $72.5 \%, 70 \%, 67.5 \%, 65.8 \%, 71.7 \%$, and $66.6 \%$ of respondents were slightly aware of weed management of swanky grass, dhedan, khabal grass, sedge family weeds, and broad leafy weeds respectively. The table shows that majority of respondents were slightly aware of pest management of dark-headed stem borer, white stem borer, yellow stem borer, planthoppers, and leafhoppers with $65 \%, 60.9 \%, 68.3 \%, 65.8 \%$, and $60.8 \%$ respectively. The table indicates that a huge majority of respondents $77.5 \%, 75.8 \%, 71.6 \%$, and $74.1 \%$ were slightly aware of disease management for the blast, brown spot, stem rot, and bacterial leaf blight respectively.

The data also depicts that nearly three fourth (73.3\%) of the farmers were not aware of manual harvesting and threshing while $35.8 \%$ of the farmers were also not aware of machine harvesting and threshing. Large percentage (80\%) of the farmers was not aware 
of combined harvesting. The majority of $(81.6 \%)$ the farmers were slightly aware of post-harvest management of cutting while $67.5 \%$ of the farmers were slightly aware of hauling as post-harvest management. Awareness about threshing was up to a slight level by $86.7 \%$ of the farmers. Almost $77.5 \%$ of the farmers were slightly aware of cleaning and field drying as post-harvest management. More than half (55.8\%) of the farmers were slightly aware of stacking or piling. Overall results of the study depict that farmers were little or not aware of the latest rice production practices. These results are in coherence with Uddin et al. (2017) who stated that farmers were not completely aware of the latest rice production technologies. However, the results also contradicted the findings by Uddin et al. (2017) who reported that farmers were least aware of transplantation practices of rice. The results also supported the findings by Uddin et al. (2017) who explained that farmers were least aware of fertilizer usage in rice, especially for fine varieties. The results were also contradicted the findings by Amponsah et al. (2018) who stated that farmers were fully aware of harvesting practices of rice. Data indicates that extension and advisory services mechanism in the research area is ineffective.

\section{Extension methodologies used by extension field staff}

In this section, respondents were asked for their responses about methodologies used by the extension field staff for the promotion of rice production technologies. The data depicting this aspect of the study is given in the Table 3, which, shows that the use of farmers' training as an extension teaching method by EFS for rice productivity was ranked first with a mean value of 3.99 and standard deviation of 0.874 . The results are also supported by findings of Ousman (2007), which revealed that if the training is conducted in a well-planned way is much helpful in changing farmers' practices. This also helps in farmer attitude towards innovation. FAO (2000) also stated that training is much important, as it is the facilitation of the learning process. The training process is vital for the adoption of new pest-control methods by farmers. The table also depicts that the use of the discussion method was ranked second extension method promoting rice production technology while the use of lectures as an extension method for promoting rice production technology was ranked third with a mean value of 3.78 and standard deviation score of 0.783 . Usage of printed materials for promoting rice production technology was ranked fourth with a mean value of 3.69 and a standard deviation value of 0.786 . Usage of demonstration method for promoting rice production technology was ranked fifth with a mean value of 3.64 and standard deviation value of 0.868 . Usage of electronic media for promoting rice production technology was ranked sixth with a mean value of 3.58 and a standard deviation value of 0.795 . Usage of Robocalls, SMS, MMS for promoting rice production technology was ranked seventh with a mean value of 3.55 and standard deviation value of 0.887 . Brainstorming was ranked least due to receiving the least mean value of 2.13 and a standard deviation score of 0.709 . The results of the study are supporting the findings by Andrango and Bergtold (2015) who stated that extension field staff least prefer electronic devices like TV and radio during their visits to farmers.

Table 3: Methodologies used by EFS for promotion of rice production technologies.

$\begin{array}{llll}\text { Methods } & \text { Mean } & \text { S.D. } & \text { Rank order } \\ \text { Farmers training } & 3.99 & 0.874 & 1 \\ \text { Discussion } & 3.83 & 0.847 & 2 \\ \text { Lecture/s } & 3.78 & 0.783 & 3 \\ \text { Printed material } & 3.69 & 0.786 & 4 \\ \text { Demonstration } & 3.64 & 0.868 & 5 \\ \text { Electronic media } & 3.58 & 0.795 & 6 \\ \text { Robo calls, SMS, MMS } & 3.55 & 0.887 & 7 \\ \text { Brainstorming } & 2.13 & 0.709 & 8\end{array}$

\section{Farmers' problems for rice productivity}

Farmers in the research area were also inquired about various problems being faced for rice production. Table 4 depicts different problems faced by farmers. The weeds problem was ranked first among the problems faced by farmers for rice productivity. This problem received the highest mean value of 3.52 with a standard deviation of 0.673 . The data also shows that insect pests and disease problems were ranked the second problem with a mean value of 3.48 and a standard deviation of 0.661 . Lack of water resources was ranked third highest problem with a mean value of 3.23 and standard deviation value of 0.796 while the unavailability of subsidies was ranked fourth with a mean value of 3.18 and standard deviation value of 0.806. Lack of credit facilities was ranked least with a mean value of 2.69 and standard deviation value of 0.818. The results of the study support the findings by Nguyen and Singh (2006) who stated that major problems faced by rice growers included technical 
problems like disease and weeds management.

Table 4: Problems faced by farmers regarding rice productivity.

\begin{tabular}{|c|c|c|c|}
\hline Problems & Mean & S.D. & $\begin{array}{l}\text { Rank } \\
\text { order }\end{array}$ \\
\hline Weeds problem & 3.52 & 0.673 & 1 \\
\hline Insects pests and diseases problem & 3.48 & 0.661 & 2 \\
\hline Lack of water resources & 3.23 & 0.796 & 3 \\
\hline Unavailability of subsidies & 3.18 & 0.806 & 4 \\
\hline $\begin{array}{l}\text { Lack of research initiative for new } \\
\text { varieties }\end{array}$ & 3.14 & 0.677 & 5 \\
\hline Unavailability of improved seed & 3.08 & 0.616 & 6 \\
\hline $\begin{array}{l}\text { Lack of implements for land prepara- } \\
\text { tion }\end{array}$ & 3.03 & 0.755 & 7 \\
\hline Natural calamities & 3.03 & 0.621 & 7 \\
\hline Costly inputs & 3.07 & 0.753 & 8 \\
\hline Lack of credit facilities & 2.69 & 0.818 & 9 \\
\hline
\end{tabular}

\section{Conclusions and Recommendations}

The current research was designed to assess awareness among farmers regarding rice production technologies being disseminated by the public sector extension and advisory services providers for rice productivity. The majority of farmers mostly receive information for rice production technologies from the department of agriculture extension and sometimes also receive information from the private sector, dealers and fellow farmers, etc. Farmers' awareness regarding various rice production technologies being transferred by the department of agriculture extension are discouraging as most of the responses indicate that farmers are 'not at all aware' and 'slightly aware' about recommended rice production technologies. 'Farmers training', 'discussion' and 'lectures' are more frequently used methods by extension field staff for promotion of rice production technologies. The most common problems of farmers regarding rice production are 'weed problem', 'insect, pest and disease problem' and lack of 'water resources'.

Following are some recommendations based on the conclusion and findings of the research:

1. Public sector extension and advisory services providers should deliver rice production technologies information more progressively. Moreover, the private sector and dealers should also be provided trainings for effective delivery of information re- lated to rice production.

2. Public sector extension and advisory services providers should confirm awareness among farmers regarding rice production technologies in rice-growing areas and particularly in the research area.

3. The public sector extension department should use interactive learning methodologies to improve learning for farmers and improve rice productivity.

4. Public sector research institutions should conduct various researches based on the problems of the farmers regarding rice production. This will minimize the issues of rice growers and also help to bridge the gap between farmers, research institutions, and advisory services providers.

\section{Novelty Statement}

This study highlights farmers' awareness regarding rice production technologies imparted by the public sector agriculture extension department. Moreover, the study recommends advisory services providers use innovative methodologies to disseminate rice production technologies in the research area.

\section{Author's Contribution}

Muhammad Yaseen: Conceived the research idea and developed research tool.

Muhammad Sallam Shahzad: Collected field data and prepared initial draft of manuscript.

Farhat Ullah Khan: Conducted data analysis and helped in preparation of research tool.

Muhammad Luqman: Assisted in data analysis, drafted research methodology and reviewed manuscript.

Usman Saleem: Assisted in instrumentation, data collection and reviewed manuscript.

Shoaib Nasir: Assisted in data analysis, proof read and finalized the manuscript.

\section{Conflict of interest}

The authors have declared no conflict of interest.

\section{References}

Ahmad, M. 2011. Causes of low yield in Pakistan: Issues \& Analysis. The Daily Dawn. Retrieved from http://www.Dawn.com (Accessed on 12 March 2021).

Ahmad, S. and H. Yohannes. 2010. Managing Food 
Price Inflation in South Asia. United Press, Dhaka, Bangladesh.

Alex, G. and W. Zijp. 2002. Rural extension and advisory services, rural development strategy background, World Bank, USA.

Amponsah, S.K., A. Addo, K. Dzisi, B. Asante and D. Afona. 2018. Assessment of rice farmers' knowledge and perception of harvest and postharvest losses in Ghana. Cogent Food and Agriculture, 4(1). Retrieved from https://www. tandfonline.com/doi/full/10.1080/23311932.2 018.1471782

Andrango, G. and J.S. Bergtold. 2015. Extension agents' preferences on teaching methods: An ordered probit with selection model. Presentation at the 2015 Agricultural \& Applied Economics Association and Western Agricultural Economics Association Annual Meeting, San Francisco, CA, July, 26-28.

Ashfaq, A., M. Ashraf and M.I.A. Khokhar. 2003. Integrated land and water resources management in Pothwar: issues and options. Sci. Int. Lahore, 15(1): 87-92.

Aslam, M. 2016. Agricultural productivity, current scenario, constraints and future prospects in $\mathrm{Pa}-$ kistan. International Water Management Institute, 12km Multan Road Chowk, Thokar Niaz Baig, Lahore 53700, Pakistan.

Ayddin, A., A.L.P. Yesilen, S.A. Vural and H.S. Guran. 2010. Determination of some agronomical characteristics and Ochratoxin-A level of Karacadag rice (Oryza sativa L.) in Diyarbakir ecological conditions Turkey. Afr. J. Agric. Res. 4(15): 1965-1972.

Babu, S.C., C.J. Glendening, K. Asenso-Okyere and S.K. Govindarajan. 2011. Farmer's information needs and search behaviors: Case study in Tamil Nadu, India. International food policy research institute IFPRI.

Bashir, M.K., Y. Mehmood and S. Hassan. 2010. Impact of agricultural credit on productivity of wheat crop: evidence from Lahore, Punjab, $\mathrm{Pa}$ kistan. Pak. J. Agric. Sci., 47(4): 405-409.

Ednhofer, O., R. Pichs-Madruga, Y. Sokona, E. Farahani, S. Kadner, K. Seyboth, A. Adler, I. Baum, S. Brunner, P. Eickemeier, B. Krieman, J. Savolainen, S. Schlomer, C.V. Stechow, T. Zwickel and J.C. Minx. 2014. Climate change mitigation: climate change contribution, working Group III to the fifth Assessment Report, Intergovernmental Panel on Climate Change-IPCC.
Cambridge University Press. Cambridge, United Kingdom and New York. NY. USA. 31p.

FAO. 2000. Export consultation on yield gape and productivity decline in rice production.

Government of Pakistan. 2019. Economic survey of Pakistan. Economic advisors wing, Finance division, Government of Pakistan, Islamabad.

Hussain, Z. 2010. Water for agriculture and future conservation strategies in the Indus basin. Retrieved from http://publications.iwmi.org/pdf/ H035789.pdf (Accessed on 2 February, 2021).

Khan, G.A. 2010. Present and prospective role of electronic media in the dissemination of agricultural technologies among farmers of the Punjab, Pakistan. Ph.D. Thesis, Department of Agricultural Extension, University of Agriculture, Faisalabad, Pakistan.

Khan. S.R.A. 2005. Introduction to extension education. P. 2-32. In Memon, R. A. and Bashir, E. (Eds) Extension Methods ( $3^{\text {rd }}$ ed.), National Book Foundation, Islamabad.

Muhammad, S. and C. Garforth. 2007. An effective communication model for the acceptance of new agricultural technology by farmers in the Punjab, Pakistan. Ph.D. thesis. Department of Agricultural Extension and Rural Development. University of Reading England.

Mwangi, M. and S. Kaiuki. 2015. Factors determining adoption of new agricultural technology by smallholder farmers in developing countries. J. Econ. Sustain. Dev., 6(5): 208-216.

Nguyen, T.C. and B. Singh. 2006. Constraints faced by the farmers in rice production and export. Omonrice, (14) 97-110.

Ousman, S. 2007. Effectiveness of agricultural development training programme: the cases of teff and livestock farmers of Alaba Woreda, Southern Ethiopia. Dire Dawa: Haramaya University.

Qamar, M. 2005. Modernizing national agricultural extension systems, Food and Agriculture Organization of the United Nations, Research extension and training division sustainable development department, United Nations.

Rajan, S.K. 1991. Determination of new strategies for improving wheat production in Loralai, Balochistan. M. Sc. (Hons.) Thesis, Department of Agricultural Extension, University of Agriculture, Faisalabad, Pakistan.

Rao, I.J. 2011. Rice grower in Pakistan. [Online] http://www.pakissan.com (Website (accessed on 18 December 2020). 
Rehman, A., L. Jingdong, B. Shahzad, AA. Chandio, I. Hussain, G. Nabi and M.S. Iqbal. 2015. Economic perspectives of major field crops of Pakistan: An empirical study. Pacific Sci. Rev. B: Human. Soc. Sci., 1(3): 145-158. https://doi. org/10.1016/j.psrb.2016.09.002

Rivera, W. and M. Qamar. 2003. Agricultural extension: rural development and the food security challenge, Food and Agriculture Organization of the United Nations, Rome.

Saeed, M.A. 2011. Constraints affecting the working efficiency of extension field staff: a case study in cotton zone of Punjab. M.Sc. (Hons.) thesis, Department of Agricultural Extension, University of Agriculture, Faisalabad, Pakistan.

Shahzadi N., M. Akhter, M. Ali and R. Misbah. 2018. Economic aspects of basmati rice in $\mathrm{Pa}$ kistan. J. Rice Res., 6: 192.

Sheikh, I. 2010. An analysis of the impact of climate change on crop yields and yield variability. Appl. Econ., 38: 835-844. https://doi. org/10.1080/00036840500193682

Siddiqui, R., G. Samad, M. Nasir and H.H. Jalil.
2012. The impact of climate change on major agricultural crops: evidence from Punjab, $\mathrm{Pa}-$ kistan. Pak. Dev. Rev., 51(4): 261-276. https:// doi.org/10.30541/v51i4IIpp.261-276

Sikkema, A. 2017. Case for radical change in agriculture sector. Retrieved from https:// resource.wur.nl/en/show/Case-for-radical-change-in-agriculture-sector.htm

Tborn, J. 2011. Adoption of agricultural innovations: Converging narratives and the role of Swedish agricultural research for development, Sweden.

Uddin, J.M., K.M.M. Billah, G.R. Akanda, M.H. Prince, M.M. Rahman, M.P. Sumon and N.H. Antor. 2017. Farmers' Knowledge on Modern Rice Cultivation Techniques at Dumki Upazilla. Int. J. Adv. Agric. Sci., 2(10): 01-07.

Zelensky, G. 1999. Rice on saline soils of Russia. In: Chataigner J. (ed.). Future of water management for rice in Mediterranean climate areas: Proceedings of the workshops. Montpellier: CIHEAM, 1999. P. 109-113, Cahiers Options Mediterraneennes, 40. 